\title{
The Role of Regional, Continental and International Organisations in Solving the Ivorian Crisis: Gains and Challenges
}

\author{
Mulalo Monyane \\ Nomonde Sibawu \\ Rachidi Molapo \\ School of Human and Social Sciences, Department of Development Studies, \\ University of Venda, Thohoyandou, Republic of South Africa \\ Email: Nomonde.Sibawu@univen.ac.za \\ Chitja Twala \\ Faculty of the Humanities, Department of History, University of the Free State, \\ Bloemfontein, Republic of South Africa \\ Email: twalacm@ufs.ac.za
}

Doi:10.5901/mjss.2014.v5n27p1073

Abstract

The study examines the role of third party mediation in trying to broker a peace agreement in the Ivory Coast. Furthermore, it highlights the reasons for the failure to implement the French brokered Linas-Marcoussis, as well as the little success of the Accra Accords. The failure of both agreements provides an understanding of events that led to the Pretoria Accords under the auspices of South Africa. In mid-2002, while L Gbagbo, the former President of the Ivory Coast was on a state visit to Italy, the country entered into its most serious political crisis since independence which was attained in 1960 under the leadership of $F$ Houphouêt-Boigny. The study argues that the implementation of the peace accords came up against a lack of goodwill by local actors. The authors contend that in the view of the international community, only by holding free and transparent elections can the Ivory Coast participate in the implementation of the peace accords.

\section{Introduction}

Discussions around the Ivorian crisis have focused almost exclusively on the supposed internal contradictions of the Ivorian state, contradictions that became glaring after former President Bedie, who replaced the country's long-term leader, Houphouêt-Boigny, enunciated the policy of Ivorite. It had been argued that the long-simmering grievances among the relatively impoverished, and largely politically marginalized inhabitants of Côte d'Ivoire's northern regions against the more favoured inhabitants of the south, were among the most important causes of the current crisis. In order to comprehend events in the Ivory Coast, the world's largest cocoa producer, one must grasp the role played by the political leadership in the area. Years 2000 and 2010 saw the Ivory Coast descend into ever greater violence. This was worsened by the results of the presidential elections which were held on 28 November 2010. After these elections, the country experienced some renewed violence and chaos that had prevailed in the area for almost a decade. After the presidential elections, supporters of Gbagbo and his rival A Ouattara, both of them claimed victory in the elections, clashed on the streets of Abidjan. Supporters of the incumbent, Gbagbo resisted efforts by the supporters of Ouattara to seize control of government buildings. The Independent Electoral Commission (IEC), the United Nations (UN), the African Union (AU), and the regional body, Economic Commission of West African States (ECOWAS) backed the IEC and endorsed Ouattara as the winner. However, the country's highest court (the Constitutional Council), allegedly comprising Gbagbo's supporters, reversed the decision by spuriously disqualifying about 400000 votes in Ouattara's strongholds. To prevent the country sliding into the 2002 civil war, regional and international organisations became involved in the crisis that faced the country. It became obvious that Gbagbo was clinging to power, denying ostracisation by the AU and the regional body, ECOWAS and threats of Western sanctions. 


\section{The Origins and Nature of the Ivorian Conflict}

The Armed Forces of Côte d'Ivoire, otherwise known as FANCl, were created in May 1960 by the government of the late Houphouêt-Boigny with a focus on creating a small army for various political and developmental activities. These included administration of the civil service and serving in other capacities as Ministers, Ambassadors and Directors in hospitals. Initially, FANCl's capacity as a fighting force was severely limited. Before the ongoing crisis, $80 \%$ of the FANCl budget was devoted to paying salaries of soldiers. This obviously had broad implications with respect to the capacity of the state to equip and defend itself. The role of FANCI changed, however, under the leadership of ex-President Bedie. Bedie's efforts to use $\mathrm{FANCI}$ in a political role, to suppress popular protests, resulted in serious tensions within the army's officer corps and rank and file, and led to the sacking of the then armed forces commander General Guei. This prompted an attempted coup d'état in 1996, and a successful one in 1999. The crisis which was later experienced had its genesis in the above mentioned events (Gberie and Addo, 2004: p9).

\section{The Issue of Conflict Resolution in Africa}

D Wilfred points out that there are two levels of dichotomous discourse when dealing with conflict resolution in Africa. They are the transference of conflict resolution vis-à-vis Africa and third world countries and the African traditional ethos of decision making. On the other hand, AR Lamin highlights the fact that South Africa once became involved in conflict resolution in the Ivory Coast and drafted the Pretoria Peace Treaty (Abdul, 2005: 1-33). Another important conflict resolution initiative to be taken into consideration was the effort led by the international community, France, ECOWAS, the $A U$ and the UN. This effort resulted in the Linas-Marcoussis Peace Agreement and the binding agreements of the Ougadougou Peace Accord. A Chryssantus postulates that: 'the Ougadougou political accord was the direct result of the non-implementation of previously negotiated agreements and international pronouncements on the conflict, the latest being the United Nations Security Council Resolution 1721' (Chryssantus, 2007: pp25-31). The provisions of the Ougadougou Peace Accord assured power sharing between the rebels and the government. It also allowed the integration of former rebels into the mainstream government activities; for example, the Ivorian Armed Forces. Spears (2000: p105) argues that: 'a second obstacle to power sharing is that parties and movements prefer to share power only as part of the strategy to boost military and political power in order to defeat enemies rather than make peace with them'.

Adding to Spear's doubt about power sharing in Africa is Marshall-Fratani's discussion of the entailment of the autochthony, nationalism, and citizenship in the war of 'who is who' in the Ivory Coast. According to him 'the leader of the parties involved in the power-sharing have a stand by grassroots support group ready to spring into action' (MarshallFratani, 2006: pp9-43). During this period, there was limited rule of law in the Ivory Coast and impunity remained an issue. There had been countless violations of human rights, arbitrary arrests of journalists and the intimidation of the civilian population. Therefore, the Ivorian conflict had created a state of corruption and a neglect of human rights.

\section{Discussion and Findings}

As early as 2002 an emergency summit of ECOWAS which was convened in Ghana, Accra resolved to dispatch a peacekeeping force to act as a buffer between the government and the rebel troops and mandated the presidents of Ghana, Niger, Guinea Bissau, Togo and Nigeria, in addition to former South African president T Mbeki to form a contact group and undertake negotiations between Gbagbo and the insurgents. However, Gbagbo was accused of being biased by the opposition and the rebels (Rametsi, 2006: p25). By 2005 the AU, ECOWAS and the international community as a whole, were all over-stretched in West Africa. They were battling to keep the lid on the cauldron in the Ivory Coast. The argument against foreign meddling had in any case been void since 1999 when the Organisation of African Unity (OAU) resolved that any government which acquired or retained power by unconstitutional means should be ostracised.

\subsection{The Linas-Marcoussis Peace Agreement}

In January 2003, the French president, J Chirac had a discussion with the political forces in the French resort town of Linas-Marcoussis. This gathering brought together representatives of all existing political parties in the Ivory Coast, as well as non-political representatives. Each delegation gave its analysis of the situation regarding the Ivorian situation and they also made suggestions aimed at restoring confidence and overcoming the crisis. The vision given by the delegations enabled the discussion table to come to a consensus agreement in which all elements, principles and extensions had the same understanding of the situation. Interestingly, the discussion table welcomed the ceasefire, made possible and 
guaranteed by the deployment of ECOWAS forces, supported by French troops, and demanded strict compliance with its terms. The Agreement repeated the need to maintain the territorial integrity of the Ivory Coast, respect for its political and economic institutions and to restore the authority of the state. It recalled its commitment to the principle of democratic accession and the exercise of power (Gberie and Addo, 2004: p16).

The Agreement provided for the formation of a Government of National Reconciliation (GNR) to ensure a return to peace and stability. It was agreed that the GNR would be led by a consensual prime minister who would remain in office until presidential elections were organised and that the interim prime minister would not be appropriate to stand as a candidate in the elections. The government would be composed of representatives from each of the delegations from the Ivory Coast that took part in the discussion table in France. In assigning ministers, a balance was to be struck among the parties throughout the term of office of the government. Three main principles which governed the Linas-Marcoussis Agreement included: The need to maintain the territorial integrity of Côte d'Ivoire; the creation of a Government of National Reconciliation, with a new Prime Minister; and the need to conduct transparent and free elections in which people would not be excluded by means of churlish legislation. Implementation of the Agreement, however, had been slow because of a lack of political will on the part of the signatories, including the government of Gbagbo. Furthermore, the Agreement itself was too ambitious because it called for a radical change of the character of the Ivorian state (Gberie and Addo, 2004: p2).

On the issue of citizenship, identity and the status of foreign nationals, the discussion table considered that the issue of citizenship as amended to make broad provisions for naturalisation by a certificate issued by the public authorities, to be generous and well drafted. The GNU was called upon to immediately promote the increased option of existing naturalisation procedures, based on improved information and possible cooperation projects which were to be implemented with the support of international development partners. The discussion table found that foreign nationals residing in large numbers in the Ivory Coast had made a major contribution to national wealth. However, the Agreement was later compromised by a lack of commitment and political will by various parties. The central issue in the conflict notably, nationality and the eligibility to run for presidential elections along with disarmament were not satisfactorily addressed. In addition, ministers belonging to the former rebel group left the GNR accusing Gbagbo of failing to delegate executive powers to the prime ministers and the coalition government, as demanded by the Agreement (Wannenburg and Giralt, 2004: p85).

The Agreement called upon Gbagbo's government and the rebels to begin the process of the disarmament programme, the respect of equality, and an end to discrimination based on identity and citizenship, as well as the need to restructure the security of the country. However, these agreements were not implemented because members of the rebel forces resigned from the government citing reasons that Gbagbo had failed to respect and implement the outcomes of the peace accord. Thus, Gbagbo was accused of having violated the agreements made in the Linas-Marcoussis Agreement and the peace process failed. France, which had 4000 peacekeepers in the Ivory Coast, along with the 6000 UN troops, had made no secret of its impatience with Gbagbo (Cornish, 2004: p14).

\subsection{The Pretoria Accords}

Before South Africa stepped in, the intention to revive the Linas-Marcoussis Agreement had already led to a series of new talks; namely, the Ghana sponsored Accra II Agreement (March 2003) which revised the power-sharing formula agreed at Kleber; the Accra III (July 2004) Agreement, promoted by the former UN Secretary, General K Annan, who attempted to topicalise Marcoussis by obtaining Gbagbo's signature. However, neither these arrangements nor the deployment of a UN peace-keeping mission on 2 April 2004 worked; thus, the Ivorian army launched the so-called Operation Dignity, a campaign of air strikes against the Mouvement Patritique de Côte d'Ivoire (MPCl) which controlled the north. Operation Dignity led to a major crisis between France and the Ivory Coast when, only two days after its start, the base of Licorne in Bouake was bombed, killing nine French soldiers. The French army retaliated by destroying the Ivorian air force, while in Abidjan most of the French population had to be evacuated following violence and pressure by the Jeunes Patriots (Pillai, 2009: p103).

Mbeki's designation as the new mediator of the Ivorian crisis came soon after the launch of Operation Dignity. The AU which had just launched its new Peace and Security Council in 2004 had an active role in the appointment of the South African mediation. Mbeki's nomination was also an indication of the ambitions and dynamism of South African diplomacy, which had already intervened in several other African crises, from the Democratic Republic of Congo (DRC) to Burundi and also Darfur. However, it was for the first time that South Africa had tried to act as a peacemaker in a former French colony and, although the Ivory Coast was a significant commercial partner for South Africa, the involvement of the latter in the Ivorian crisis before 2004 had been limited. With respect to France, post-apartheid South Africa had on its 
side the legitimacy that hailed from its undoubted status in the African political arena. Ouattara remarked that the fact that South Africa knew the Ivorian situation far less than France did was not necessarily a disadvantage. For Gbagbo, the arrival of Mbeki at such critical moment was welcomed, both because it represented the first serious alternative to a peace process dominated by France or by the French-speaking members of ECOWAS. He saw in Mbeki's political background and nationalist convictions the possibility of influencing the South African President. Mbeki's efforts to restore peace in the Ivory Coast received a boost on Friday 17 December 2004 after a meeting with Ivorian rebel forces in Pretoria. L Dacoury-Tabley, deputy chief of the New Forces rebel group, said the group would no longer delay the peace process (Vapi, 2004: p4).

Probably not by chance, Mbeki summoned a meeting in Abidjan on 9 November 2005, while the city was de facto under French occupation and the confrontation between French troops and the demonstrators' attitudes worsened. Gbagbo's effort to draw a misleading parallel between the post-colonial oppression allegedly suffered by the Ivory Coast and apartheid South Africa seemed, at first, to produce its effects on Mbeki and on his collaborators. Apparently shocked by what he had seen in November in Abidjan and afraid that the application of targeted sanctions could further worsen the political climate and hinder his mediation efforts, Mbeki pushed the UN to postpone their application.

Since being entrusted to lead the peace process, Mbeki had persuaded both the rebels and the government to agree on key divisive issues, including disarmament, security and legislative reform, to pave the way for reconciliation and elections.

\subsection{The United Nations and the imposition of sanctions}

On 22 November 2004, the United Nations Security Council (UNSC) took a decision to impose an arms embargo on the Ivory Coast, with the possibility of further sanctions. According to the UNSC, this was necessary to halt the spiral into chaos in what was once West Africa's oasis of stability and relative prosperity. The simmering conflict in the Ivory Coast threatened the region which had already been buffeted by brutal war and crises. It was also a broader security concern because terrorist organisations had established sanctuaries in West Africa.

Over the years Gbagbo had, all along, insinuated that France wanted to have Ouattara as President of the Ivory Coast. In 2011, it was the UN Secretary-General's Special Representative, YJ Choi who sparked the debate that he had independently checked them and found no good reason for the Constitutional Council to overturn the IEC's verdict that Ouattara had won (Fabricius, 2011: p16). With the above reaction, it was clear that Choi was fulfilling his mandate as he understood it, to safeguard Ivorian democracy by giving his honest verdict on the election results.

On 27 January 2011, the Central Bank of West African States slammed the seizure of its Ivorian branch by forces loyal to Gbagbo. Troops surrounded the bank's offices in Abidjan, intensifying a struggle over funds between Gbagbo and his rival Ouattara who had won the presidential election on 28 November 2010. The bank had moved to block Gbagbo's access to Ivorian accounts, and said that it recognised Ouattara as the country's president. The squeeze on the banking system followed a string of international measures, including asset freezes and bans on doing business with Gbagbo supporters and institutions.

\subsection{The role played by the African Union (AU)}

In November 2004, Gbagbo's forces violated the ceasefire and used helicopters to attack peace-keeping positions, killing nine French soldiers and an American aid worker; in retaliation, the French launched an attack. When the AU called for an emergency meeting to discuss the situation, Gbagbo skipped the event. The tragedy for the Ivory Coast was that the damage to the fabric of society, as well as to the economy would be almost impossible to reverse (Farah, 2004: p15).

In January 2011, the AU agreed to set up a panel to help resolve the Ivory Coast's political crisis, with its conclusions to be delivered within a month. According to the AU, the November 2010 presidential election was supposed to open a more positive chapter in Ivory Coast's history, almost 8 years after a civil war that had split the nation into the mainly Muslim north and Christian south. Instead, the poll provoked a violent crisis in which more than 270 people were killed. The problem started when Gbagbo refused to hand over the reins of power to Quattara, the man the electoral commission declared the winner. He subsequently overturned the results which sparked unrest.

In view of the problems facing the Ivory Coast, AU Commissioner, J Ping stated: 'The panel will conclude its work within a period not exceeding one month and the conclusions, which will be endorsed by the council, will be binding on all the Ivorian parties with which the conclusion would have been negotiated' (Anon, 2011: p10). Supporting the above sentiments, Kenyan Prime Minister, R Odinga alluded to the following concerning the role of the AU Summit: 'This summit must send a strong and unequivocal message that the two parties must negotiate face to face. Given (Ivory Coast's) long 
history of strife and civil war, and with the preparations for armed conflict under way on both sides, a small spark could ignite a major conflagration that would also threaten the region's stability' (Anon, 2011: p10). Furthermore, Odinga reported: 'Ivory Coast symbolizes the great tragedy that seems to have befallen Africa, whereby some incumbents are not willing to give up power if they lose' (Anon, 2011: p10). It is clear from the above that the declaration the AU made was not about the use of force; the organisation was committed to a peaceful solution to the Ivory Coast's problems.

After the presidential elections of 28 November 2010, former South African President T Mbeki had already cast doubt on the regional and international consensus in favour of Ouattara when he reported to AU Commission chairperson, Ping that there were no angels or devils in the Ivory Coast conflict and that the AU should renegotiate a settlement of the frequently negotiated crisis.

\subsection{The role of ECOWAS}

On 5 October 2002 the West African mediators arrived in a rebel stronghold of the Ivory Coast for talks with insurgents on ending a 15-day rebellion that had thrown the region into turmoil. Ministers from five West African countries, including regional ally Nigeria, aboard French military helicopters landed in Bouake, the Ivory Coast's second largest city. The first priority was to promote a ceasefire. Bouake fell to the rebels on 19 September when their coup against Gbagbo failed. Gbagbo said he was ready to agree to the ceasefire, but the government was anxious not to accept a de facto separation of the country between the north and south (Thomson, 2002: p8).

On the basis that Ouattara had won the presidential election of 28 November 2010, ECOWAS initially wanted to forcefully remove Gbagbo from the presidency, as well as impose economic sanctions, primarily an embargo on the prime export, cocoa and a financial squeeze which were starting to be felt despite Gbagbo's aggressive resistance (Fabricius, 2011: p16).

By January 2011, ECOWAS threatened to send troops to the Ivory Coast to remove Gbagbo. He was clinging to power with the backing of the army. Gbagbo's attitude of clinging to power caused ECOWAS to change its tune and opt for a peaceful solution to the country's problems. It became clear that ECOWAS did not want to solve the Ivory Coast's problems by using force. However, the organisation was ready to deploy other measures if peaceful negotiations could not be reached.

Matters were further complicated by Ghana's failure to send troops to oust Gbagbo from office. This stance by Ghana was against the move by the 15 nations in West Africa to militarily intervene in the Ivory Coast. Ghana's President stated: 'Ghana's position is that even though we support the decision by ECOWAS to send a force to Ivory Coast, Ghana finds itself unable to contribute troops because they are overstretched. Currently Ghana has 500 soldiers on UN Mission in Ivory Coast' (Anon, 2011: p16).

\section{The Failures of Regional and International Organisations to Bring Peace}

Rarely had any crisis been the subject of so many attempted international mediations and summit meetings to try to normalise the situation in a trouble-torn West Africa. By 2011 there were voices in Africa and elsewhere in the world calling for a military invasion of the Ivory Coast to force Gbagbo out of power. One of the most strident voices was that of Odinga, who had, rather oddly been appointed AU mediator in the Ivory Coast. Voices calling for caution were rather muted and appeared to be in the minority. By 2011, the efforts to bring peace and stability in the area proved a failure. The various arbitrators who had succeeded one another in attempting to sort out the conflict, proved to be largely incompetent and ultimately failed. Above all, the skilful manoeuvring of Gbagbo, who, from the very beginning of the crisis wanted to remain in power, was seen as a poor negotiator. Since the crisis began, the attitude of France appeared uncertain, if not downright contradictory to the Linas-Marcoussis Agreement, signed in January 2003. Thus, France tried to marginalise Gbagbo but without any success.

\section{Conclusion}

This study shows that war is brutal, nasty and unpredictable. In most cases, it is the ordinary civilians who carry no weapons and at times, know very little about the issues behind the conflict who bear the brunt of the violence. Several options have been implemented in the Ivory Coast in an effort to restore order, but with little success. Despite all the attempts by regional and international organisations to bring about peace in the area, the country continues to be deeply divided between the north and south. The north continues to be under the firm control of the rebel army of the Forces Nouvelles, while the south is controlled by the national defence forces. The holding of elections in the Ivory Coast without 
dealing with the process of demobilising the rebel army has contributed to the escalation of violence. France's stationing of military forces in the country as a whole has been accepted by everyone in the Ivory Coast.

The study has attempted to demonstrate that international and regional efforts to solve the Ivorian dispute have been, above all, marked by massive confusion and unusual disorganisation. Constantly, new actors have become involved and old ones have changed positions, while others have remained critical of Gbagbo without having a clear approach to the problem, thus adding insecurity to the trouble-torn area. What has also complicated matters is the fact that when many have criticised Gbagbo and produced unclear threats of military intervention, others have remained politically loyal to the same goal throughout the entire period. In the absence of operative democratic institutions and a participative civil society capable of keeping checks and balances advanced by the national constitution, in the case of the Ivory Coast, diplomatic changes have not achieved the desired political or humanitarian results.

\section{References}

Abdul AL. 'The conflict in Côte d'Ivoire: South Africa's diplomacy and prospects for peace', Institute for Global Dialogue, Johannesburg: August: P1-33.

Anon 2011. 'Military option mulled in Ivory Coast', City Press, 9 January: P16.

Anon 2011. 'AU's new move to end Ivory Coast's post-election crisis and prevent civil war', Sunday Independent, 30 January: P10.

Cornish JJ 2004. 'Côte d'Ivoire peace deal touch-and-go', Weekly Mail and Guardian, 12 August: P14.

Chryssantus A 2007. 'Peace in Côte d'Ivoire: An analysis of the Ouagadougou Peace Accord', Conflict Trends, 25: PP: 25-31.

Fabricius P 2011. 'Tragedy if AU balked at historical challenge', Star, 28 January: P16.

Farah D 2004. 'Sanctions give Ivory Coast's president pause for thought', Sunday Independent, 28 November: P15.

Gberie $L$ and Addo P 2004. 'Challenges of Peace Implementation in Cote d'Ivoire', Presentation at the Expect Workshop by the Kofi Annan International Peacekeeping Training Centre (KAIPTC) and the Center for International Peace Operations (ZIF), Accra, Ghana, 31 May-2 June: P16.

Marshall-Fratani R 2006. 'The war of who is who: Autochthony, Nationalism, and Citizenship in the Ivorian Crisis', African Studies Review Studies, 19(2): PP9-43.

Rametsi S 2006. 'South Africa's Diplomatic Involvement as a peace-broker in West Africa: The case of Côte d'Ivoire', Unpublished MA Dissertation, University of the Witwatersrand, Johannesburg: P25.

Spears I 2000. 'Understanding Inclusive Peace Agreement in Africa, the problems of sharing power', Third World Quarterly 21(1), February: P105.

Vapi X 2004. 'Breakthrough for Mbeki on Ivory Coast', Sunday Times, 19 December: P4.

Wannenburg G and Giralt N 2004. 'West Africa: A review of the region', South African Yearbook of International Affairs 2003/2004, Johannesburg: South African Institute of International Affairs: P85. 